\title{
Analisis senyawa volatil dari ekstrak tanaman yang berpotensi sebagai atraktan parasitoid telur wereng batang coklat, Anagrus nilaparvatae (Pang et Wang) (Hymenoptera: Mymaridae)
}

\author{
Volatile analysis from extraction of potential plant for \\ attractant of egg parasitoid of brown planthopper, \\ Anagrus nilaparvatae (Pang et Wang) \\ (Hymenoptera: Mymaridae)
}

\author{
Surjani Wonorahardjo ${ }^{1}$, Nurindah ${ }^{2 *}$, Dwi Adi Sunarto² ${ }^{2}$ Sujak $^{2}$, Neena Zakia ${ }^{1}$ \\ ${ }^{1}$ Jurusan Kimia, Fakultas Matematika dan Ilmu Pengetahuan Alam, Universitas Negeri Malang \\ Jalan Semarang 5, Malang 65145 \\ ${ }^{2}$ Balai Penelitian Tanaman Pemanis dan Serat. Badan Penelitian dan Pengembangan Pertanian, \\ Kementerian Pertanian, Jalan Raya Karangploso, Kotak Pos 199, Malang
}

(diterima Oktober 204, disetujui Januari 2015)

\begin{abstract}
ABSTRAK
Tanaman dapat menghasilkan senyawa volatil sebagai sarana komunikasi intra- atau inter- spesies. Tanaman yang terinfeksi herbivora akan memproduksi senyawa volatil sebagai mekanisme pertahanan tidak langsung yang dapat menarik musuh alami herbivora tersebut. Analisis senyawa-senyawa volatil yang diproduksi oleh tanaman padi akibat infestasi telur wereng batang coklat (WBC) dilakukan untuk mengidentifikasi komponen penyusun senyawa volatil yang berpotensi sebagai atraktan bagi parasitoid telur WBC, Anagrus nilaparvatae (Pang et Wang) (Hymenoptera: Mymaridae). Kegiatan penelitian ini merupakan tahap awal dari pembuatan formula atraktan parasitoid WBC, meliputi ekstraksi senyawa volatil dari batang padi yang tidak terinfestasi dan terinfestasi telur WBC dengan menggunakan pelarut aseton dan n-heksana, analisis komponen senyawa volatil dengan menggunakan gas kromatografi spektroskopi massa (GC-MS), dan bioassay perilaku orientasi parasitoid terhadap senyawa volatil dengan metode olfaktometri. Metode ekstraksi yang digunakan adalah teknik maserasi dan ekstraksi kontinyu yang diikuti dengan pemekatan. Bioassay perilaku orientasi A. nilaparvatae dilakukan dengan menggunakan olfaktometer tabung $\mathrm{Y}$ dan untuk setiap lot bioassay digunakan 30 parasitoid telur yang diulang 3 kali. Hasil analisis menunjukkan bahwa senyawa volatil yang terdapat pada ekstrak tanaman padi yang terinfestasi telur WBC terdiri atas 16 komponen. Komponen dengan proporsi tertinggi pada metode dengan pelarut aseton adalah 2-Pentanon, 4-hidroksi-4-methil $(19,9 \%)$, sedangkan dengan pelarut n-heksana adalah asam heksanadioat, dioktil ester (65\%). $A$. nilaparvatae menunjukkan respon positif terhadap ekstrak tanaman padi yang terinfestasi telur WBC sehingga senyawa volatil yang terdapat pada ekstrak tanaman padi yang terinfestasi telur WBC dapat dimanfaatkan sebagai atraktan $A$. nilaparvatae untuk mendukung pengelolaan hama padi yang ramah lingkungan.
\end{abstract}

Kata kunci: volatil, atraktan, Nilaparvata lugens, parasitoid

\footnotetext{
ABSTRACT

Plants produce volatiles as communication cues intra- or inter- species. Infested plants by herbivores will produce volatiles as indirect defense mechanism that attracts natural enemies of

*Penulis korespondensi: Nurindah. Balai Penelitian Tanaman Pemanis dan Serat, Badan Penelitian dan Pengembangan Pertanian, Kementerian Pertanian, Jalan Raya Karangploso, Kotak Pos 199 Malang

Tel: 031-491447, Email: nurindah@litbang.deptan.go.id
} 
herbivores. Analysis of volatiles compounds produced by rice plant as result of infested brown plant hopper (BPH), Nilaparvata lugens Stâl, was done to identify compounds in the volatiles that potentially can be used as attractant for egg parasitoids of BPH, Anagrus nilaparvatae (Pang et Wang) (Hymenoptera: Mymaridae). This research was an early stage to develop formulation of parasitoid attractant. The research activities include volatiles extraction of infested rice stem by BPH eggs using acetone, $\mathrm{n}$-hexane as the extraction solvents; analyses of volatile compounds with GC-MS; and bioassay of parasitoid orientation behavior to the volatiles using olfactometer methods. Extraction methods applied were maceration and continuous extraction followed by concentration. Bioassay on the parasitoid orientation behavior was done by using Y-tube olfactometer and every lot of bioassay using 30 parasitoid females with 3 replicates. The results showed that the volatile compounds of extract of infested rice stem by BPH eggs comprise of 16 components. The highest proportion of the components extracted with acetone is 2-Pentanone, 4-hydroxy-4-methyl (19,9\%), while those with n-hexane is Hexanedioic acid, dioctyl ester (65\%). A. nilaparvatae showed positive response to the volatiles extracted from infested rice plant by $N$. lugens eggs. Therefore, the volatiles can be used as an attractant for the egg A. nilaparvatae to support rice pest management.

Key words: attractant, parasitoid, planthopper, volatiles

\section{PENDAHULUAN}

Tanaman memiliki mekanisme pertahanan diri dari serangan herbivora dengan menghasilkan senyawa-senyawa yang berfungsi untuk membangun resistensi tanaman (Riyals et al. 1994), atau sebagai mekanisme pertahanan tidak langsung dengan menarik musuh alami (Green \& Ryan 1972; Paré \& Tumlinson 1999). Secara alami, tanaman yang terinfestasi herbivora akan aktif menghasilkan berbagai senyawa volatil, yang dikenal dengan istilah Herbivore-induced plant volatiles (HIPVs) (Turlings \& Ton 2006). Fungsi utama dari HIPVs adalah untuk pertahanan tanaman terhadap herbivora dan patogen, menarik polinator, dan organisme berguna lainnya, termasuk parasitoid (Dudareva \& Pichersky 2008). Jasmonide acid (JA) dan methyl jasmonate (MeJA) atau yang biasa disebut sebagai jesmonates (JAs) merupakan senyawa yang terlibat dalam mekanisme pertahanan tanaman (Peña-Cortés et al. 2005). JA merupakan senyawa volatil yang berperan penting sebagai signal untuk pertahanan tanaman akibat pelukaan oleh wereng (SenthilNathan et al. 2009; Tebayashi et al. 2007; Thaler et al. 2002).

Pemanfaatan senyawa volatil yang diproduksi oleh tanaman sebagai akibat dari infestasi serangga herbivora untuk menarik musuh alami (atau biasa disebut atraktan), merupakan salah satu aksi dalam sistem pengendalian hama secara hayati sebagai komponen utama dalam sistem pengendalian hama terpadu. Senyawa volatil yang diproduksi oleh tanaman sebagai reaksi dari infestasi herbivora dapat diekstraksi dengan menggunakan metode baku, seperti maserasi secara berulang untuk menjaga keutuhan komponen penyusun senyawa volatil tersebut (Wonorahardjo 2013). Walaupun demikian, penelitian pemanfaatan atraktan musuh alami berupa senyawa volatil yang diekstrak dari tanaman belum dilakukan secara intensif di Indonesia.

Nilaparvata lugens Stâl, wereng batang coklat (WBC) merupakan serangga penghisap cairan tanaman padi (Oryza sativa L.) dan merupakan hama utama pada pertanaman padi di Indonesia dengan luas serangan yang mencapai $20.000 \mathrm{ha} /$ tahun. Serangan wereng pada padi menyebabkan pengurangan produksi secara substansial, bahkan dapat menyebabkan gagal panen atau puso. Oleh karena itu, serangan wereng padi dapat mengancam tercapainya target swasembada pangan. Sejak tahun 2000-an peningkatan serangan wereng juga terjadi di beberapa negara di Asia (Catiding et al. 2009; Matsumura et al. 2009). Hal ini menunjukkan bahwa sistem pengendalian populasi WBC hingga pada tingkat yang tidak merusak masih belum optimal.

Sistem pengendalian wereng padi yang diterapkan oleh petani adalah sistem pengendalian hama secara terpadu (PHT) dengan menggunakan varietas tahan, pergiliran tanaman dan memanfaatkan musuh alami (Laba 2010). Penggunaan agens hayati dalam pengendalian wereng padi harus dioptimalkan karena pada ekosistem padi tersedia sedikitnya 59 spesies parasitoid (Yaherwandi 2009) dan 6 jenis predator wereng yang potensial (Kartohardjono 2011). Secara alami, mortalitas wereng padi oleh parasitoid dan predatornya dapat mencapai 38\% (Lubis 2005). Walaupun 
potensi musuh alami WBC telah diketahui, pengelolaan musuh alami untuk pengendalian hayati WBC sebagai komponen utama PHT padi, masih belum banyak dilakukan (Catiding et al. 2009). Salah satu pengelolaan musuh alami, khususnya parasitoid, untuk meningkatkan perannya sebagai agens pengendali adalah dengan memanfaatkan fenomena alam yang ada, yaitu interaksi tritrofik antara tanaman inang (padi), herbivora (wereng padi) dan parasitoid. Anagrus spp. merupakan parasitoid yang sering dijumpai memarasit telur WBC pada tanaman padi dan dapat dijadikan model pemanfaatan HIPV sebagai atraktan parasitoid telur tersebut. Oleh karena itu, penelitian in bertujuan untuk menganalisis senyawa volatil dari ekstrak tanaman padi yang terinfestasi telur WBC dan berpotensi untuk dikembangkan sebagai atraktan parasitoid telur Anagrus nilaparvatae (Pang et Wang).

\section{BAHAN DAN METODE}

\section{Penyediaan stok tanaman padi}

Tanaman padi dipersiapkan dengan menggunakan bibit padi dari varietas yang rentan terhadap WBC, yaitu IR-64. Benih padi direndam dalam air selama 24 jam, kemudian dicuci dengan air dan dikering-anginkan selama 24 jam. Untuk perbanyakan WBC, benih disemai ke dalam wadah plastik (diameter $15 \mathrm{~cm}$, tinggi $3 \mathrm{~cm}$ ) yang telah diisi tanah dan ditambahkan air secukupnya. Wadah plastik tersebut kemudian diselubungi dengan plastik transparan setinggi $50 \mathrm{~cm}$ dan bagian atasnya ditutup kain kassa. Bibit padi berumur 7 hari setelah semai siap digunakan untuk diinfestasi telur WBC dan pakan untuk perbanyakan $\mathrm{WBC}$, parasitoid telur $\mathrm{WBC}$, dan sebagai bahan ekstraksi senyawa volatil.

\section{Ekstraksi dan identifikasi senyawa volatil tanaman padi}

Ekstraksi senyawa volatil dari tanaman padi dilakukan untuk padi yang tidak terinfestasi WBC (tanaman sehat) dan tanaman padi yang terinfestasi telur WBC. Ekstraksi dilakukan di Laboratorium Sentral Kimia, Fakultas Matematika dan Ilmu Pengetahuan Alam, Universitas Negeri Malang. Metode ekstraksi yang digunakan adalah teknik maserasi dan ekstraksi kontinyu yang diikuti dengan pemekatan. Maserasi dilakukan untuk menarik senyawa-senyawa yang dapat larut tanpa pemanasan. Pelarut yang digunakan dalam ekstraksi adalah asam organik (aseton) untuk menarik senyawa-senyawa polar atau setengah polar, maupun pelarut non-polar (n-heksana) untuk menarik senyawa-senyawa non-polar atau senyawa bermassa molekul besar.

Ekstraksi dilakukan dengan membersihkan dan memotong kecil-kecil $200 \mathrm{~g}$ batang padi sehat maupun yang telah terinfestasi telur WBC secara terpisah. Potongan batang yang telah bersih diletakkan dalam beaker glass dan ditutup aluminium foil. Potongan batang padi, baik yang terinfestasi telur WBC maupun yang sehat, secara terpisah masing-masing direndam dalam $300 \mathrm{ml}$ aseton dan $300 \mathrm{ml}$ n-heksan selama 48 jam. Hasil ekstraksi dipisahkan dengan teknik filtrasi dan ekstrak disimpan di dalam refrigerator suhu 5$7{ }^{\circ} \mathrm{C}$ dalam botol gelap dan tertutup sebelum diuji dengan GC MS.

Identifikasi komponen senyawa volatil dilakukan dengan memisahkan masing-masing komponen dengan kromatografi gas sekaligus menganalisis struktur tiap komponen dengan menggunakan spektroskopi massa. Adapun gas pembawa yang digunakan adalah Helium dengan laju total $20 \mathrm{ml} / \mathrm{menit}$ dan laju dalam kolom 0,5 $\mathrm{ml} /$ menit, suhu kolom dalam ovien $60{ }^{\circ} \mathrm{C}$ ditahan 5 menit dan perlahan-lahan dinaikkan sampai $300{ }^{\circ} \mathrm{C}$ dan ditahan selama 41 menit. Suhu sumber ion $250{ }^{\circ} \mathrm{C}$, suhu interface $305{ }^{\circ} \mathrm{C}$ dengan cut time (waktu pengukuran MS) dimulai dari menit ke-3,75. Kromatogram yang diperoleh diberi nama sesuai dengan anjuran Library Wiley 8. Komponen senyawa yang komposisinya lebih besar dari 4\% dikategorikan sebagai komponen dominan, sedangkan tingkat kesesuaian sebesar $90 \%$ dengan library digolongkan pasti.

\section{Bioassay perilaku orientasi parasitoid terhadap senyawa volatil esktrak tanaman padi}

Pada umumnya, parasitoid dari Ordo Hymenoptera menggunakan signal olfatori dalam proses penemuan inang dengan menunjukkan perilaku orientasi yang pertama pada habitat inang dan kemudian orientasi pada inangnya (Vinson 1981; Waseloh 1981). Oleh karena itu, untuk 
mengetahui perilaku orientasi parasitoid dalam menemukan inangnya diperlukan uji olfaktometri.

Pengujian senyawa volatil sebagai atraktan terhadap parasitoid wereng padi dilakukan di Laboratorium Biokontrol, Balai Penelitian Tanaman Pemanis dan Serat (Balittas).

Penyediaan WBC. Pemeliharaan WBC dimulai dari induk yang dikumpulkan dari lapang. Sebanyak 50 pasang WBC diintroduksikan dalam sangkar tanaman padi berumur 7 hari untuk peletakan telur. Betina WBC akan meletakkan telur sekitar 3-4 hari dan setelah 5-7 hari telur akan menetas menjadi nimfa. Nimfa dipelihara hingga menjadi imago dan jika tanaman telah menguning dilakukan infestasi ke tanaman baru dengan cara memindahkan wereng dewasa ke bibit sehat berumur 14-20 hari. Penyediaan stok wereng ini dilakukan secara terus menerus untuk penyediaan inang parasitoid maupun untuk penyediaan bahan tanaman yang terinfeksi wereng untuk diekstraksi.

Penyediaan parasitoid. Parasitoid telur, $A$. nilaparvatae yang digunakan berasal dari lapang yang dikumpulkan dengan metode pemerangkapan. Tanaman padi yang digunakan untuk memeragkap A. nilaparvatae adalah tanaman berumur 3 minggu yang telah diinfestasi telur dan ditempatkan di sawah selama dua hari. Setelah dua hari digunakan sebagai perangkap, tanaman dibawa ke laboratorium dan diselubungi dengan plastik transparan setinggi $50 \mathrm{~cm}$, yang pada bagian atasnya ditutup kain kassa.

A. nilaparvatae yang muncul dipelihara dalam sangkar yang terbuat dari bahan plastik transparan (diameter $12 \mathrm{~cm}$, tinggi $25 \mathrm{~cm}$ ), bagian bawah sangkar digunakan cawan petri plastik diameter $12 \mathrm{~cm}$ sebagai tempat ditaruhnya bibit padi yang telah terinfestasi telur wereng, sedang bagian atas sangkar ditutup kain kassa untuk aerasi. Penyediaan parasitoid telur dilakukan dengan memaparkan telur WBC pada batang padi kepada A. nilaparvatae. Pemaparan telur terhadap parasitoid dilakukan selama 4-5 hari. Pada bagian samping atas sangkar pemeliharaan parasitoid ini dipasang tabung kaca yang menghadap ke cahaya. Tabung kaca ini berfungsi sebagai tempat pengumpul parasitoid karena pada umumnya parasitoid bersifat fototaksis positif. Parasitoid dikumpulkan setiap hari dengan mengganti tabung kaca tersebut dan siap digunakan dalam bioassay.

Bioassay perilaku orientasi $A$. nilaparvatae terhadap volatil ekstrak tanaman. Bioassay perilaku orientasi $A$. nilaparvatae dilakukan dengan menggunakan olfaktometer tabung $\mathrm{Y}$ (Lou \& Cheng 1996; Lou \& Cheng 2005; Meilin 2012; Rapusas et al. 1996; Wang et al. 2008) yang dimodifikasi. Olfaktometer terdiri atas tabung Y (diameter 1,5 cm), tabung sumber bau (berupa silinder gelas diameter $10 \mathrm{~cm}$, tinggi 20 $\mathrm{cm})$, sumber aerator dengan kapasitas 1,5 1/menit, tabung gelas berisi arang aktif sebagai filter, silinder gelas penampung bau dengan humidifier, flowmeter (series RMA, Rate Master Flowmeter, Dwyer Instrument Inc., USA) dengan kapasitas aliran udara $150 \mathrm{ml} /$ menit, dan sumber cahaya 10 watt. Pengujian dilakukan sesuai dengan masa aktif (diel pattern) parasitoid. Berdasarkan pengamatan pada uji pendahuluan masa aktif A. nilaparvatae yang ditandai dengan foraging behaviour, yaitu pada pukul 08:00-11:00. Kondisi lingkungan pengujian pada suhu ruang $25 \pm 2{ }^{\circ} \mathrm{C}$ dan kelembaban udara $60-80 \%$.

Tahap awal bioassay adalah validasi olfaktometer tabung Y dengan melakukan uji preferensi A. nilaparvatae terhadap volatil tanaman padi sehat dan tanaman yang telah terinfestasi telur WBC. Jika olfaktometer telah tervalidasi, dilakukan bioassay lanjutan, yaitu uji preferensi $A$. nilaparvatae terhadap senyawa volatil dari ekstrak tanaman yang terinfestasi telur WBC dan senyawa volatil dari ektrak tanaman sehat.

Pada uji tahap pertama (validasi olfaktometer) tanaman padi yang telah diinfestasi telur WBC dan tanaman padi sehat berumur 4 minggu dicabut dan dibersihkan dengan menggunakan kertas tissue. Masing-msing jenis tanaman tersebut kemudian dimasukkan dalam tabung sumber bau dan kemudian ditutup rapat. Satu betina A. nilaparvatae secara individu dimasukkan melalui ujung tabung Y dan diamati respon parasitoid tersebut, yaitu gerakan parasitoid yang diasumsikan sebagai perilaku orientasi parasitoid terhadap bau yang berasal dari masing-masing ujung tabung Y. Pengamatan dibatasi hingga 10 menit per individu parasitoid. Parasitoid yang menunjukkan respon terhadap bau pada salah satu tangan tabung Y dan 
dikategorikan memilih adalah jika berada pada tangan tabung $\mathrm{Y}$ sepanjang $>6 \mathrm{~cm}$ dari dasar tangan selama \pm 1 menit. Jumlah individu parasitoid yang memilih sumber bau tanaman dengan infestasi telur WBC $(\mathrm{R}+)$ dan tanaman tanpa infestasi telur WBC (R-) dicatat. Jika selama 10 menit individu parasitoid tidak melakukan pemilihan maka individu tersebut dianggap tidak mempunyai respon (NR). Setelah satu kali pengujian, tabung Y dibersihkan dengan alkohol 70\% dan dikeringkan. Untuk satu set pengujian ini digunakan 30 betina parasitoid ( $\mathrm{n}=30$ ), dan pengujian ini diulang $3 \mathrm{kali}$.

Uji tahap kedua dilakukan seperti uji tahap pertama, tetapi tanaman diganti dengan ekstrak tanaman yang dimasukkan dalam tabung gelas sebagai sumber bau, yaitu ekstrak tanaman tanpa infestasi telur WBC dan ekstraksi tanaman dengan infestasi telur WBC, masing-masing menggunakan metode pelarut aseton dan $n$-heksana. Volatil ekstrak tanaman yang didatangi oleh individu parasitoid terbanyak menunjukkan senyawa volatil yang paling potensial sebagai atraktan $A$. nilaparvatae.

\section{HASIL}

\section{Ekstraksi dan identifikasi senyawa volatil batang tanaman padi terinfestasi telur WBC}

Ekstraksi tanaman padi yang terinfestasi dan tidak terinfestasi WBC dengan menggunakan pelarut aseton dan $n$-heksana menghasilkan 4 ekstrak, seperti tercantum pada Tabel 1. Hasil analisis komponen penyusun senyawa volatil dominan dari ekstrak dengan pelarut aseton tersaji pada Tabel 2 dan ekstrak dengan pelarut $n$-heksana pada Tabel 3. Hasil analisis ekstrak tanaman terinfestasi telur WBC dengan pelarut aseton menunjukkan adanya

Tabel 1. Hasil ekstraksi batang padi yang tidak terinfestasi dan terinfestasi telur wereng batang coklat (WBC)

\begin{tabular}{ll}
\hline Kode ekstrak & \multicolumn{1}{c}{ Keterangan } \\
\hline Inf-As & Ekstrak batang padi yang terinfestasi telur WBC dengan menggunakan pelarut aseton \\
Uninf-As & Ekstrak batang padi yang tidak terinfestasi telur WBC dengan menggunakan pelarut aseton \\
Inf-Hex & Ekstrak batang padi yang terinfestasi telur WBC dengan menggunakan pelarut $n$-heksana \\
Uninf-Hex & $\begin{array}{l}\text { Ekstrak batang padi yang tidak terinfestasi telur WBC dengan menggunakan pelarut } \\
n \text {-heksana }\end{array}$ \\
\hline
\end{tabular}

Tabel 2. Proporsi komponen senyawa volatil dominan dari ekstrak tanaman padi yang terinfestasi dan tidak terinfestasi telur wereng batang coklat dengan pelarut aseton

\begin{tabular}{lcc}
\hline \multirow{2}{*}{ Nama senyawa } & \multicolumn{2}{c}{$\%$ dalam profil } \\
\cline { 2 - 3 } & Tidak terinfestasi & Terinfestasi \\
\hline 2-Propanon, 1-hidroksi- & & 6,31 \\
2-Pentena, 3,4-dimetil & & 12,59 \\
2-Pentanon, 4-hidroks-4-metil & & 5,92 \\
2-Heksanon, 3,4-dimetil- & & 3,15 \\
2-Propen-1-ol & & 4,40 \\
2,3-dihidro-3,5-dihidroksi-6-metil-4h-piran-4-on & & 16,46 \\
2-Furankarboksaldehid, 5-(hidroksmetil)- & 4,50 \\
9-Oktadekanoat asam (Z)- & & 3,90 \\
Fitol & & \\
Oktadekanal, 2-bromo- & 4,81 & \\
Oktadecanoat asam, 2-okso-, metil ester & 12,97 & \\
Oktadekanal & 35,76 \\
Oktadekanoat asam, 2-okso-, metil ester & 6,18 \\
6-Nitro-sikloheksadekana-1,3-dione & 24,11 \\
Eikosan, 3-sikloheksil- & 7,05 \\
\hline
\end{tabular}


9 senyawa komponen yang dominan, sedangkan ekstrak dari tanaman yang tidak terinfestasi tersusun dari 6 komponen senyawa dominan yang berbeda dengan ekstrak tanaman terinfeksi WBC. Hasil analisa ekstrak tanaman terinfestasi telur WBC dengan pelarut $n$-heksana menunjukkan adanya 4 senyawa komponen dominan, sedangkan ekstrak dari tanaman yang tidak terinfeksi tersusun dari 9 komponen.

Hasil ekstraksi dengan pelarut aseton menunjukkan komposisi senyawa yang berbeda antara tanaman yang tidak terinfestasi dan terinfestasi telur WBC. Perbedaan ini terlihat sebagai senyawasenyawa baru yang tidak terdapat dalam volatil ektrak tanaman sehat. Senyawa-senyawa baru ini setelah dilakukan identifikasi pada NIST62 Library merupakan senyawa-senyawa keton, aldehid, alkohol, serta senyawa-senyawa hidrokarbon jenuh. Ekstrak volatil dengan pelarut aseton pada padi sehat menunjukkan kehadiran senyawa-senyawa asam, ester, aldehid dan juga keton (Tabel 3). Pada dasarnya senyawa-senyawa ini akan mengalami dekomposisi menjadi senyawa-senyawa baru dan hal ini didukung pula oleh ditemukannya beberapa senyawa hidrokarbon rantai panjang yang mengandung ikatan rangkap. Kehadiran oksigen di udara menyebabkan peluang besar terjadinya reaksi oksidasi pada senyawa-senyawa ini dan menghasilkan senyawa-senyawa baru yang mempunyai efek berbeda di udara.

Hasil ekstraksi dengan pelarut $n$-heksana menunjukkan senyawa-senyawa mirip antara ekstrak dari tanaman yang terinfestasi dan tidak terinfestasi telur WBC, namun komposisinya berbeda. Volatil yang diekstrak dari tanaman terinfestasi telur
WBC dengan menggunakan pelarut $n$-heksana proporsi dari senyawa penyusunnya mengalami perubahan dari volatil ekstrak tanaman sehat, terutama proporsi senyawa asam heksadioat, dioktil ester (Tabel 3). Tetapi perubahan proporsi ini bukan berarti kandungan senyawa tersebut meningkat, karena angka tersebut merupakan proporsi dari campuran senyawa-senyawa yang ada dalam volatil. Tetradekanal merupakan satu senyawa baru yang ditemukan dalam ekstrak volatil tanaman terinfestasi WBC.

\section{Bioassay perilaku orientasi $A$. nilaparvatae terhadap senyawa volatil ekstrak batang padi terinfestasi telur WBC}

Validasi alat olfaktometer dilakukan untuk mengevaluasi olfaktometer yang digunakan. Pendekatan validasi alat ini dilakukan dengan menguji orientasi perilaku $A$. nilaparvatae terhadap volatil yang diproduksi tanaman yang terinfestasi telur WBC dibandingkan dengan respon parasitoid tersebut terhadap volatil tanaman yang tidak terinfestasi telur WBC. Hasil pengujian menunjukkan bahwa jumlah individu yang menunjukkan $\mathrm{R}+$ terhadap sumber bau tanaman dengan infestasi telur WBC lebih banyak dibandingkan dengan jumlah individu parasitoid yang menunjukkan respon negatif (R-), yaitu individu yang berorientasi pada sumber bau dari tanaman yang tidak terinfestasi telur WBC; dan parasitoid yang tidak menunjukkan respon (NR) terhadap kedua volatil tersebut (Tabel 4). Hasil ini menunjukkan bahwa parasitoid memperlihatkan respon positif atau berorientasi pada sumber bau tanaman yang terinfestasi telur WBC.

Tabel 3. Proporsi komponen senyawa volatil dominan dari ekstrak tanaman padi yang terinfestasi dan tidak terinfestasi telur wereng batang coklat dengan pelarut $n$-heksana

\begin{tabular}{lcc}
\hline \multirow{2}{*}{ Nama senyawa } & \multicolumn{2}{c}{$\%$ dalam profil } \\
\cline { 2 - 3 } & Tidak terinfestasi & Terinfestasi \\
\hline Heksadioat asam, dioktil ester & 25,58 & 65,82 \\
Heneikosana (2) & 8,14 & 4,27 \\
1-eikosanol & 9,69 & 5,29 \\
Tetradekanal & & 7,15 \\
1-eikosanol & 9,69 & \\
Eikosana & 5,24 & \\
1-dokosanol & 3,87 & \\
Heksadekanal & 5,71 & \\
Unknown 1 & 4,01 & \\
Oktadekanal & 5,24 & \\
\hline
\end{tabular}


Dengan demikian, olfaktometer tabung $\mathrm{Y}$ yang dimodifikasi ini dapat digunakan untuk bioassay volatil ekstrak tanaman padi tanpa infestasi dan terinfestasi telur WBC. Hal ini mempunyai arti bahwa jika parasitoid menunjukkan perilaku orientasi pada sumber bau volatil ekstrak tanaman padi dengan infestasi telur WBC $(\mathrm{R}+)$ maka volatil tersebut mengandung komponen senyawa yang dapat menarik parasitoid untuk mendatanginya.

Jumlah individu $A$. nilaparvatae yang menunjukkan $\mathrm{R}+$ pada volatil inf-As dan volatil inf- $n$-heksana lebih banyak dibandingkan dengan jumlah individu yang menunjukkan R- dan NR (Tabel 4). Data ini menunjukkan bahwa volatil ekstrak tanaman yang terinfestasi telur WBC dengan metode ekstraksi menggunakan pelarut aseton atau $n$-heksana mempengaruhi orientasi A. nilaparvatae untuk mendatangi sumber bau tersebut.

\section{PEMBAHASAN}

Hasil analisis komponen senyawa volatil ekstrak tanaman padi yang terinfeksi telur WBC menunjukkan komposisi yang berbeda dengan hasil analisis Lou \& Cheng (1996) terhadap ekstrak tanaman padi yang telah terinfestasi wereng $N$. lugens. Hasil analisis Lou \& Cheng (1996) tidak menunjukkan adanya senyawa baru, tetapi volatil yang diproduksi komposisinya berubah. Hasil analisa kromatografi dari ekstrak dengan pelarut aseton maupun $n$-heksana tidak menunjukkan komponen N-heptadecane yang merupakan komponen yang dominan pada tanaman yang terinfestasi $N$. lugens dan proporsinya bertambah dari komposisi pada tanaman yang tidak terinfestasi. Perbedaan hasil ini kemungkinan disebabkan oleh berbedanya metode ekstraksi yang dilakukan. Dalam penelitian ini ekstraksi dilakukan dengan pelarut organik sehingga tidak hanya senyawasenyawa volatil yang terambil namun juga banyak komponen dari batang padi itu sendiri termasuk senyawa-senyawa penyusun protein dan karbohidrat pada batang padi beserta telur WBC pada padi terinfestasi. Sedangkan Lou \& Cheng (1996), ekstraksi dilakukan hanya pada senyawa volatil yang dikeluarkan dari tumbuhan tanpa merusak jaringan tumbuhan itu sendiri dan gasgas yang tertangkap di permukaan penjerap mikro (SPME) kemudian dianalisis dengan GC MS. Walaupun terdapat perbedaan komponen penyusun senyawa volatil dari penelitian ini dan hasil Lou \& Cheng (1996), volatil dari ekstrak tanaman padi yang terinfestasi telur WBC dapat memengaruhi orientasi A. nilaparvatae terhadapnya (Tabel 4).

Selain itu, Lou \& Cheng (1996) mengekstraksi tanaman yang teinfestasi WBC, bukan tanaman yang terinfestasi telur WBC saja, seperti pada penelitian ini. Tanaman yang terinfestasi WBC mengalami pelukaan karena adanya oviposisi telur ke dalam jaringan dan pelukaan jaringan tanaman akibat penusukan stilet WBC untuk menghisap cairan dalam batang padi. Dua jenis pelukaan yang berbeda (oleh ovipositor dan stilet) menyebabkan tanaman memproduksi senyawa metabolit sekunder yang berbeda sehingga menunjukkan bahwa karakter senyawa volatil yang diproduksi spesifikasinya tinggi (Dudareva \& Pichersky 2008).

Tetradekanal merupakan satu senyawa dalam volatil yang dihasilkan oleh tanaman yang terinfestasi telur WBC dengan menggunakan pelarut $n$-heksana dalam proses ekstraksinya. Telah dilaporkan oleh Zeid (2002) bahwa tetradekanal merupakan satu senyawa metabolit yang dihasil-

Tabel 4. Uji perilaku orientasi parasitoid terhadap volatil ekstrak batang padi yang terinfestasi telur wereng batang coklat $(\mathrm{n}=30)$ dalam uji olfaktometri tabung $\mathrm{Y}$

\begin{tabular}{lccc}
\hline \multirow{2}{*}{ Sumber bau } & \multicolumn{3}{c}{ Perilaku orientasi parasitoid } \\
\cline { 2 - 4 } & $\mathrm{R}+$ & $\mathrm{R}-$ & $\mathrm{NR}$ \\
\hline Tanaman terinfestasi telur wereng batang coklat & $21 \mathrm{a}^{1}$ & $6 \mathrm{~b}$ & $3 \mathrm{~b}$ \\
Volatil-As & $22 \mathrm{a}$ & $1 \mathrm{~b}$ & $7 \mathrm{~b}$ \\
Volatil- $n$-heksana & $26 \mathrm{a}$ & $3 \mathrm{~b}$ & $1 \mathrm{~b}$ \\
\hline
\end{tabular}

${ }^{1}$ angka pada baris yang sama yang diikuti oleh huruf yang berbeda menunjukkan perbedaan yang nyata $(\mathrm{P}<0,05)$ berdasarkan uji BNT.

$\mathrm{R}+$ : individu parasitoid yang menunjukkan respon positif terhadap sumber bau; R-: individu parasitoid yang menunjukkan respon negatif terhadap sumber bau; NR: individu parasitoid yang tidak menunjukkan respon terhadap sumber bau. 
kan oleh tanaman karena perlakuan pemberian larutan tembaga (II) klorida yang disebut sebagai stress metabolite. Proses oviposi telur WBC dalam jaringan tanaman padi kemungkinan menyebabkan tanaman memproduksi stress metabolite berupa senyawa tetradekanal sehingga senyawa ini terdeteksi sebagai komponen senyawa volatil ekstrak tanaman padi yang terinfestasi telur WBC.

Hasil bioassay menunjukkan bahwa volatil yang diproduksi oleh tanaman yang terinfestasi telur WBC mampu menarik A. nilaparvatae. Untuk perbandingan, (Meilin 2012) menggunakan olfaktometer yang serupa untuk menguji respon A. nilaparvatae terhadap volatil yang dihasilkan oleh residu deltametrin pada konsentrasi subletal dan mendapatkan bahwa parasitoid telur tersebut menunjukkan respon negatif terhadap volatil residu insektisida tersebut. Kondisi ini merupakan kenyataan yang sudah banyak dilaporkan bahwa penyemprotan insektisida berpengaruh negatif terhadap perkembangan populasi parasitoid (misalnya Jin et al. 2014; Liu et al. 2012; Sohrabi et al. 2013; Paine \& Hanlon 2011).

Bioassay orientasi perilaku parasitoid terhadap empat jenis volatil dari ekstrak yang didapatkan menunjukkan bahwa jumlah individu A. nilaparvatae yang menunjukkan respon positif $(\mathrm{R}+)$ terhadap volatil ekstrak tanaman yang terinfestasi telur WBC, baik yang dengan metode pelarut aseton maupun $n$-heksana, lebih banyak dibandingkan dengan yang menunjukkan respon positif (R-) terhadap volatil pelarut (aseton $/ n$ heksana) maupun yang tidak menunjukkan respon (NR) (Tabel 4). Hasil ini menunjukkan bahwa parasitoid mengenali volatil sebagai petunjuk untuk menemukan inang (host location) yang ditunjukkan dengan orientasinya pada sumber bau dari volatil ekstrak batang padi yang terinfestasi telur WBC.

Methyl-jasmonade acid (MeJA) diketahui sebagai senyawa yang dapat memicu tanaman untuk memproduksi (E)- $\beta$-caryophyllene dari golongan terpenoid yang dapat menarik $A$. nilaparvatae (Cheng et al. 2007). Sementara itu, Krugner et al (2014) melaporkan bahwa formulasi sintetik berupa campuran volatil ekstrak tanaman yang terdiri atas (E)- $\beta$-ocimene atau (E,E)- $\alpha$ farnesene dapat digunakan oleh parasitoid telur
Gonatocerus ashmeadi Girault (Hymenoptera: Mymaridae) untuk menemukan inangnya.

Hasil analisis kimia senyawa-senyawa volatil dari ekstrak tanaman yang terinfestasi telur WBC komposisinya berbeda dengan komposisi senyawa volatil dari ekstrak tanaman padi yang telah dilaporkan (misalnya Lou \& Cheng 1996; Cheng et al. 2007). Akan tetapi, sebenarnya senyawa-senyawa penyusun volatil tersebut termasuk dalam golongan-golongan yang sama, hanya berbeda deret homolognya. Hasil pengujian orientasi parasitoid terhadap volatil ekstrak batang padi yang terinfestasi telur WBC menunjukkan bahwa $A$. nilaparvatae memperlihatkan respon positif terhadap volatil yang diektrak dengan menggunakan pelarut aseton maupun $n$-heksana. Hal ini menunjukkan bahwa senyawa ekstrak tanaman padi yang terinfestasi telur WBC hasil penelitian ini dapat dimanfaatkan untuk atraktan parasitoid. Rapusas et al. (1996) melaporkan predator wereng Cirtorhinus lividipennis Reuter lebih tertarik pada volatil tanaman padi yang teinfestasi telur WBC dibandingkan dengan yang terinfestasi nimfa WBC. Dengan demikian maka ekstrak tanaman padi yang terinfestasi telur WBC kemungkinan juga dapat dimanfaatkan sebagai atraktan parasitoid telur maupun predator WBC.

Proses ekstraksi volatil dengan metode maserasi untuk tanaman yang terinfestasi telur WBC ini memungkinkan senyawa-senyawa kimia dari telur WBC yang terdapat di dalam batang juga terekstrak. Akan tetapi, dari hasil analisis GC-MS komponen senyawa volatil yang diekstrak dari tanaman padi terinfestasi telur WBC dengan menggunakan pelarut polar (aseton) dan nonpolar ( $n$-heksana) teridentifikasi sebagai senyawasenyawa yang tergolong metabolit sekunder yang telah dilaporkan diproduksi oleh tanaman sebagai akibat adanya infestasi oleh herbivora. Senyawasenyawa tersebut bersifat sangat spesifik (Lou et al. 2006) dan berbeda dengan protein yang merupakan kandungan utama telur serangga yang tidak volatil. Dalam proses ekstraksi volatil dengan metode maserasi ini sebagian protein mengendap bersama dengan kumpulan senyawa sejenisnya dan tidak terekstrak, tetapi teringgal sebagai ampas maserasi. Oleh karena itu, senyawa volatil yang terekstrak dari tanaman padi yang terinfestasi telur 
WBC dengan metode maserasi ini dapat dipastikan merupakan hasil metabolit sekunder tanaman padi sebagai reaksi tanaman untuk memberi sinyal pada parasitoid telur A. nilaparvatae yang akan menggunakannya sebagai cues untuk menemukan inang (host location). Dengan demikian, senyawa volatil yang diekstrak dari tanaman padi IR-64 yang terinfestasi telur WBC dapat dikembangkan menjadi formula atraktan untuk A. nilaparvatae

\section{KESIMPULAN}

A. nilaparvatae menunjukkan respon positif terhadap ekstrak tanaman padi yang terinfestasi telur WBC. Senyawa volatil yang terdapat pada ekstrak tanaman padi yang terinfestasi telur WBC terdiri atas 16 komponen, dengan proporsi tertinggi dengan pelarut aseton adalah 2-Pentanon, 4-hidroksi-4-metil (19,9\%), sedangkan dengan pelarut $n$-heksana adalah asam heksadionat, dikotil ester (65\%). Senyawa-senyawa komponen volatil tersebut dapat dikembangkan untuk dimanfaatkan sebagai atraktan A. nilaparvatae untuk mendukung pengelolaan hama padi yang ramah lingkungan.

\section{UCAPAN TERIMA KASIH}

Penulis mengucapkan terima kasih kepada para penelaah naskah hasil penelitian ini dengan masukan-masukannya yang konstruktif sehingga naskah ini menjadi lebih baik dan informatif. Naskah ini merupakan sebagian dari kegiatan penelitian dengan sumber dana dari Program Riset Sinergi Nasional (SINas), Kementerian Riset dan Teknologi tahun anggaran 2012.

\section{DAFTAR PUSTAKA}

Catiding JL, Arida GS, Baehaki SE, Bentur JS, Cuong LQ, Norowi M, Rattanakam W, Sriratanasak W, Xia J, Lu Z. 2009. Situation of planthopper in Asia. In: Heong KHB (Eds.), Planthoppers: New Threats to the Sustainability of Intensive Rice Production System in Asia. Los Banos: International Rice Research Institute.
Cheng AX, Xiang CY, Li JX, Yang CQ, Hu WL, Wang LJ, Lou YG, Chen XY. 2007. The rice (E)$\beta$-caryophyllene synthase (OsTPS3) accounts for the major inducible volatile sesquiterpenes. Phytochemistry 68:1632-1641. doi: http://dx.doi. org/10.1016/j.phytochem.2007.04.008.

Constabel CA, Ryan CA. 1998. A survey of wound and methyl jasmonate-induces leaf polyphenol oxidase in crop plants. Phytochemistry 47:507511. doi: http://dx.doi.org/10.1016/S0031-9422 (97)00539-6.

Dudareva N, Pichersky E. 2008. Metabolic engineering of plant volatiles. Current Opinion in Biotechnology 19:181-189. doi: http://dx.doi. org/10.1016/j.copbio.2008.02.011.

Green TR, Ryan C. 1972. Wound induces proteinase inhibitor in plant leaves: a possible defense mechanism against insects. Science 175:776-777. doi: http://dx.doi.org/10.1126/science.175.4023. 776.

Jin T, Lin Y, Jin Q, Wen H, Peng Z. 2014. Sublethal effect of avermectin and acetamiprid on the mortality of different life stages of Brontispa longissima (Gestro) (Coleoptera: Hispidae) and its larvae parasitoid Asecodes hispinarum Bouček (Hymenoptera: Eulophidae). Crop Protection 58:55-60. doi: http://dx.doi.org/10.1016/j.cropro. 2013.12.025.

Kartohardjono A. 2011. Penggunaan musuh alami sebagai komponen pengendalian hama padi berbasis ekologi. Pengembangan Inovasi Pertanian 4:29-46.

Krugner R, Wallis CM, Walse SS. 2014. Attraction of the egg parasitoid, Gonatocerus ashmeadi Girault (Hymenoptera: Mymaridae) to synthetic formulation of a (E)- $\beta$-ocimene and $(\mathrm{E}, \mathrm{E})-\alpha$ farnesene mixture. Biological Control 77:23-28. doi: http://dx.doi.org/10.1016/j.biocontrol.2014. 06.005 .

Laba IW. 2010. Analisis empiris penggunaan insektisida menuju pertanian berkelanjutan. Pengembangan Inovasi Pertanian 3:130-137.

Liu F, Zhang X, Gui QQ, Xu QJ. 2012. Sublethal effects of four insecticides on Anagrus nilaparvatae (Hymenoptera: Mymaridae), an important egg parasitoid of the rice planthopper Nilaparvata lugens (Homoptera: Delphacidae). Crop Protection 37:13-19. doi: http://dx.doi. org/10.1016/j.cropro.2012.02.012.

Lou Y, Cheng J. 1996. The behavioral responses of Anagrus nilaparvatae Pang et Wang to the volatiles of rice varieties. Entomological Journal of East China 5:60-64. 
Lou YG, Ma Cheng B. 2005. Attraction of the parasitoid Anagrus nilaparvatae to rice volatiles induced by the rice brown planthopper Nilaparvata lugens. Journal of Chemical Ecology 31:2357-2372. doi: http://dx.doi.org/10.1007/ s10886-005-7106-z.

Lou Y, Hua X, Turlings TCJ, Cheng J, Chen X. 2006. Differences in induced volatile emissions among rice varieties result in differential attraction and parasitism of Nilaparvata lugens eggs by the parasitoid Anagrus nilaparvatae in the field. Journal of Chemical Ecology 32:2375-2387. doi: http://dx.doi.org/10.1007/s10886-006-9151-7.

Lubis Y. 2005. Peranan keanekaragaman hayati arthropoda sebagai musuh alami pada ekosistem padi sawah. Jurnal Penelitian Bidang Ilmu Pertanian 3:16-24.

Matsumura M, Takeuchi H, Satoh M, Morimura SS, Otuka A, Watanabe T, Thanh DV. 2009. Current status of insecticide resistance in rice planthoppers in Asia. In; Heong K, Hardy B (Eds.), Planthoppers: New Threats to The Sustainability of Intensive Rice Production System in Asia (pp. 233-244). Los Banos: International Rice Research Institute.

Meilin A. 2012. Dampak Aplikasi Insektisida Pada Parasitoid Telur Wereng Batang Cokelat Dan Deltametrin Konsentrasi Subletal Terhadap Anagrus nilaparvatae (Hymenoptera: Mymaridae). Yogyakarta: Universitas Gajah Mada.

Paré PW, Tumlinson JH. 1999. Plant volatiles as defence against insect herbivores. Plant Physiology 121:325-331. doi: http://dx.doi. org/10.1104/pp.121.2.325.

Peña-Cortés H, Barrios P, Dorta F, Polanco V, Sánchez C, Sánchez E, Ramírez I. 2005. Involvement of jasmonic acid and derivatives in plant responses to pathogens and insects and in fruit ripening. Journal of Plant Growth Regulation 23:246-260.

Rapusas HR, Bottrell DG, Coll M. 1996. Intraspecific variation in chemical attraction of rice to insect predators. Biological Control 6:394-400. doi: http://dx.doi.org/10.1006/bcon.1996.0050.

Riyals J, Uknes S, Ward E. 1994. Systemic aquarired resistance. Plant Physiology 104:1109-1112.

Senthil-Nathan S, Kalaivani K, Man-Young C, ChaeHon P. 2009. Effect of jasmonic acid-induced resistance in rice on the brownhopper Nilaparvata lugens Stal (Homoptera: Delphacidae). Pesticide
Biochemistry and Physiology 95:77-84. doi: http://dx.doi.org/10.1016/j.pestbp.2009.07.001.

Sohrabi F, Shishehbor P, Saber M, Mosaddegh MS. 2013. Lethal and sublethal effects of imidacloprid and buprofezin on the sweetpotato whitefly parasitoid Eretmocerus mundus (Hymenoptera: Aphelinidae). Crop Protection 45:98-103. doi: http://dx.doi.org/10.1016/j.cropro.2012.11.024.

Paine TD, Hanlon CC, Byrne FJ. 2011. Potential risks of systemic imidacloprid to parasitoid natural enemies of a cerambycid attacking Eucalyptus. Biological Control 56:175-178. doi: http:// dx.doi.org/10.1016/j.biocontrol.2010.08.007.

Tebayashi S, Horibata Y, Mikagi E, Kashiwagi T, Mekuria DB, Dekebo A, Ishihara A, Kim C. 2007. Introduction of resistance against the leafminer, Liriomyza trifolii, by jasmonic acid in sweet pepper. Bioscience, Biotechnology and Biochemistry 71:1521-1526. doi: http://dx.doi. org/10.1271/bbb.70033.

Thaler JS, Farag MA, Pare PW, Dicke M. 2002. Jasmonate-deficient plants have reduced direct and indirect defences against herbivores. Ecology Letters 5:764-774. doi: http://dx.doi.org/10.1046/ j.1461-0248.2002.00388.x.

Turlings TCJ, Ton J. 2006. Exploiting scents of distress: the prospect of manipulating herbivoreinduced plant odours to enhance the control of agricultural pests. Current Opinion in Plant Biology 9:421-427. doi: http://dx.doi. org/10.1016/j.pbi.2006.05.010.

Wang HD, Chen JP, Zhang HM, Sun XL, Zhu JL, Wang AG, Sheng WX, Adams MJ. 2008. Recent rice stripe virus epidemics in Zhejiang province, China, and experiments on sowing date, disease-yield loss relationships, and seedling susceptibility. Plant Disease 92:1190-1196. doi: http://dx.doi.org/10.1094/PDIS-92-8-1190.

Wonorahardjo S. 2013. Metode-Metode Pemisahan Kimia, Sebuah Pengantar. Jakarta: Akademia Permata.

Yaherwandi. 2009. Struktur komunitas hymenoptera parasitoid pada berbagai lanskap pertanian di Sumatra Barat. Jurnal Entomologi Indonesia $6: 1-14$

Zeid AHSA. 2002. Stress metabolites from Corchorus olitorius L. leaves in response to certain stress agents. Food Chemistry 76:187-195. doi: http:// dx.doi.org/10.1016/S0308-8146(01)00264-3. 